\title{
THE MICROBIAL COMPONENT IN SPANISH AQUATIC ECOSYSTEMS
}

\author{
R. Guerrero' ${ }^{1}$ and C. Pedrós-Alió ${ }^{2}$ \\ I Department of Microbiology, University of Barcelona. Spain. \\ 2 Marine Sciences Institute, CSIC, Barcelona, Spain.
}

Keywords: Microbial ecology, Heterotrophic bacteria, Phototrophic bacteria, Flagellates, Ciliates, Plankton, Phagotrophy.

Regions of sorrow, doleful shades, where peace

And rest can never dwell; hut torture without end

Still urges, and a fiery Deluge, fed

With ever-burning Sulphur unconsumed:

Such place Eternal Justice had prepar'd...

John Milton, Paradise Lost (1667)
A lake is the landscape's most beautiful and expressive feature. It is earth' eye; looking into which the beholder. measures thedepth of his own nature. The fluviatile trees next the shore are the slender eyelashes which fringe it, and the wooded hills and cliffs around are its overhanging brows.

Henry D. Thoreau, Walden (1854)

Ecology is physiology in the worst possible conditions.

Thomas D. Brock (1966) citing one of his distressed students.

\begin{abstract}
Spain has a wide variety of aquatic ecosystems with peculiar chemical composition and hydrological regimes. Microorganisms are the sole inhabitants of many of these sytems and a very important component in most. Studies of microbial ecology in Spanish ecosystems, therefore, provide examples of both "conventional" and "peculiar" environments, where hypotheses about the role of microorganisms can be tested. This paper provides an overview of the studies of microorganisms carried out in Spanish aquatic ecosystems and summarizes their contributions to the current paradigm of the bacterioplankton.
\end{abstract}

\section{INTRODUCTION}

Microbial ecology is an extremely young discipline. The first book with such a title was published only 25 years ago (BROCK, 1966). A good method to determine the number of bacteria in natural waters, for example, was only established 15 years ago, and no satisfactory technique yet exists to determine total production of bacterioplankton. Initially, microbial ecology was only a ragbag of disciplines of applied microbiology in which the Environment had to be considered: pollution microbiology, environmental microbiology, microbial leaching of minerals, nitrogen fixation by symbiotic associations, biogeochemical cycling of nutrients, and so on. The introduction of techniques from medical microbiology, cell and molecular biology and bacterial physiology during the seventies and eighties has completely transformed the discipline. Nowadays microbial ecology is a field in its own, with efforts centered in the understanding of the ecology of microorganisms. Moreover, the perspective provided by microbial ecology is considered to give the best possible approach to the understanding of other widely different fields such as biotechnology or medical microbiology. In order to fulfill such high hopes, microbial ecology needs to incorporate the ideas and concepts from general ecology and to improve the techniques for the study of microorganisms in situ.

Within the field of limnology, the past 15 years have witnessed a change of paradigm. The classical food chain (diatom to copepod to fish), has been shown to be only a part of the whole picture. This was already proposed by POMEROY in 1974, but only in the last ten years were techniques available to probe its intrincacies and to provide quantitative data. After a paradigm becomes established, the exceptions to the rules are probably more interesting than 
most "orthodox" systems. Studies carried out in Spain offer examples of both orthodox and "heretic" microbial ecosystems. The latter, however, have received considerably more attention in our country, in particular the ecology of phototrophic bacteria has been intensively studied. This is perhaps, due to the abundance of "peculiar" aquatic environments in Spain, which can be considered to be exceptions

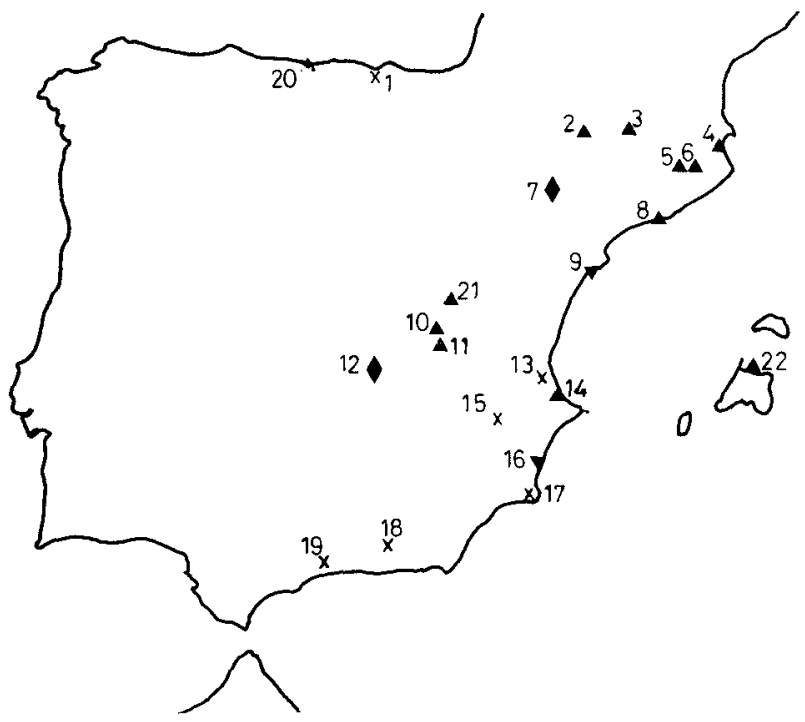

Figure I. Map of the Iberian Peninsula with the location of study sites. Triangles pointing up indicate systems with planktonic communities of sulfur phototrophic bacteria. Triangles pointing down indicate systems with benthic communities of phototrophic bacteria. Empty circles indicate systems without communities of phototrophic bacteria. 1. Butron River (Biscaia); 2. Lake Estanya (Huesca); 3. Lake Montcortés (Lleida); 4. La Massona Coastal lagoon (Girona); 5. Sant Miquel de Campmajor karstic region with Lakes Negre and Coromines (Girona); 6. Banyoles karstic region with Lakes Banyoles, Ciso, and Vilar (Girona); 7. Chiprana hypersaline pond (Zaragoza); 8. Remolar coastal lagoon (Barcelona); 9. Alfacs Bay in the Ebro Delta (Tarragona); 10. Torcas karstic region, with Laguna de la Cruz and Lagunillo del Tejo (Cuenca); I I. Arcas2 and other karstic lakes (Cuenca); 12. Hypersaline lagoons in the endorheic region around Alcázar de San Juan (Ciudad Real); 13. Albufera de Valencia shallow coastal lagoon (Valencia); 14. Cullera coastal lagoon (Valencia); 15. Pétrola hyperasaline lagoon (Albacete); 16. Santa Pola saltworks (Alicante); 17. Mar Menor, shallow coastal lagoon (Murcia); 18. La Caldera, high mountain lake (Granada); 19. La Concepcidn reservoir (Málaga); 20. Santoña coastal lagoon (Santander); 21. Lake El Tobar (Cuenca); 22. Cibollar coastal lagoon (Mallorca).

to the rules (fig. 1). These rules, however, have been defined after the study of a biassed sample of world ecosystems (WILLIAMS, 1988). Therefore, the study of these "peculiar" systems should be rewarding and fascinating.

In this chapter we will first summarize the current paradigm of the plankton. Then, relevant studies carried out in
Spain will be reviewed. Finally, studies of aquatic ecosystems which do not fit this paradigm will be considered. Environmental and pollution microbiology will not be considered. Likewise, phytoplankton studies will be dealt with in other chapters.

\section{THE CURRENT PARADIGM OF THE HETEROTROPHIC MICROBIAL PLANKTON}

Numerous studies have recently established a new paradigm of the plankton. A few statements form the basis of this model:

a) Primary production is considered to be carried out mostly by the pico- and nanoplankton.

b) Bacterioplankton biomass in widely different aquatic systems is close to $20 \%$ of phytoplankton biornass (BIRD \& KALFF, 1984), although it can be higher than $100 \%$ or lower than $10 \%$ (DUCKLOW \& CARLSON, 1992).

C) Bacterioplankton heterotrophic production is thought to be around $50 \%$ of primary production (COLE et al., 1988, DUCKLOW \& CARLSON, 1992). The former is not only supported by primary production, however, but also by allocthonous inputs of dissolved and particulated organic matter.

d) Both the phototrophic and heterotrophic picoplankton are eaten by a large collection of microorganisms, ranging in size from viruses up to rotifers and crustaceans. Most of these predators select food particles based on their size, although some are able to taste food particles before either ingesting or rejecting them.

e) The slopy feeding activities of these predators, together with their excretion, generate dissolved and particulate organic matter, and nutrients which become available to phyto- and bacterioplankton.

f) The largest of these predators are adequate as food for large invertebrates and vertebrate predators and, thus, close the microbial loop: from phytoplankton to bacteria, to heterotrophic flagellates, to ciliates, to rotifers and crustaceans, to fishes (AZAM et al., 1984).

\section{THE HETEROTROPHIC BACTERIA IN SPANISH AQUATIC ECOSYSTEMS}

a) Studies of phytoplankton and primary production will be dealt with in other chapters of the present book. 
b) and c) Bacterial biomass has been estimated in the Banyoles lakes, the Butrón river, a collection of continental ponds, Mar Menor, La Concepcidn reservoir and La Caldera lake (fig. 1). Bacterial production has been studied in Lake Cisó and in the Butron river using the $3 \mathrm{H}$-thymidine (TdR) incorporation technique.

In the Butrón river bacterial abundance was recorded separately for free-living and attached bacteria. The former varied between 0.7 and $2.2 \times 10^{6}$ cells $\mathrm{mL}^{-1}$ (average 1.42) and the latter between 1.7 and $6.3 \times 10^{5}$ cells $\mathrm{mL}^{-1}$ (average 3.9) (IRIBERRI er al., 1990a). By a filtration-dilution procedure, IRIBERRI et al., (1990b) showed that similar percentages of the free-living biomass (78\%) and of the attached biomass (53\%) were actively dividing. Production, as determined by TdR incorporation into cold TCA-insoluble material was similar for both bacterial fractions: $5.8 \mathrm{ngC} \mathrm{mL}^{-1}$ $\mathrm{h}^{-1}$ for the free-living and 2.97 for the attached bacteria (IRIBERRI et al.. 1990a). Thus, 67\% of total heterotrophic production was accounted for by the free-living bacteria. Doubling times were around 6 hours for both assemblages. In addition, IRIBERRI et al., (1990a) determined conversion factors for attached and free-living assemblages separately and found them to be very similar.

In Lake Ciso, bacterial heterotrophic production was determined by the same TdR method (GARCIA CANTIZANO et al., in preparation). Many of the parameters necessary to optimize the technique were shown to vary vertically, from the aerobic epilimnion to the sulfide-rich hypolimnion. Thus, saturating concentrations of $\mathrm{TdR}$ were different and isotope dilution experiments gave different results. Activity was generally higher at the metalimnion than at the epilimnion. Lowest activities were always found at the hypolimnion, with values similar to those found throughout the lake during holomixis (when the lake is completely anaerobic). Purple sulfur bacteria were found to incorporate TdR in autoradiograms. This occurred at some winter dates, but did not occur the rest of the year. Apparently, these bacteria are able to photoassimilate thymidine under some conditions. Using literature conversion factors, total bacterial heterotrophic production was about $120 \%$ of primary production This was probably due to the small size of the lake which favors heavy allocthonous inputs of organic matter

A survey of Spanish continental äquatıc ecosystems was carried out during 1988 and1989 by a team of ecologists, geologists and microblologists (MONTES, 1990) The purpose of the survey was to build an up-to-date catalog of Spanish wetlands and lakes. Most of the effort was put into non microbial organisms, but some parameters of microbiological interest were determined. These were total bacterial counts, electron transport activity (ETS), poly-Bhydroxybutyrate (PHB) concentrations, and pigment concentrations (including chlorophyll $a$ and bacteriochlorophylls). Since most of these parameters are indicators of biomass, they tended to covariate. Thus, a relationship between bacterial numbers and chlorophyll $a$ was found (fig. 2), which was in general agreement with that of BIRD \& KALFF (1984). Many of the systems studied were peculiar in some way or another: hypersaline endorheic ponds, soda lakes, salinas, sulfide rich meromictic lakes and so on. The study had the virtue of putting together a tremendous amount of information about these systems. In the future, it should be simple to choose any given system for particular experimental purposes.

A different approach was taken by J. Rodriguez and collaborators (ECHEVARRIA et al., 1990; GILABERT et al., 1990; RODRIGUEZ et al., 1990). These authors were interested in the size distribution of organisms in different aquatic systems. They measured the size spectra, including the bacterial size classes, in La Caldera (ECHEVARRIA et al., 1990; RODRIGUEZ et al., 1990), a high mountain oligotrophic lake, the Mar Menor (GILABERT et al., 1990), a large coastal lagoon, and the $\mathrm{La}$ Concepción reservoir (ECHEVARRIA, 1991). An example of the data can be seen in fig. 3. The same approach has also been used in Lake Cisó (GASOL et al., 1991b). These studies have shown the variability of size spectra through the seasonal cycles and across systems. Another aspect analyzed has been the secondary scaling of the size spectra. In Lake La Caldera for example, there is an overall relationship between biomass and body

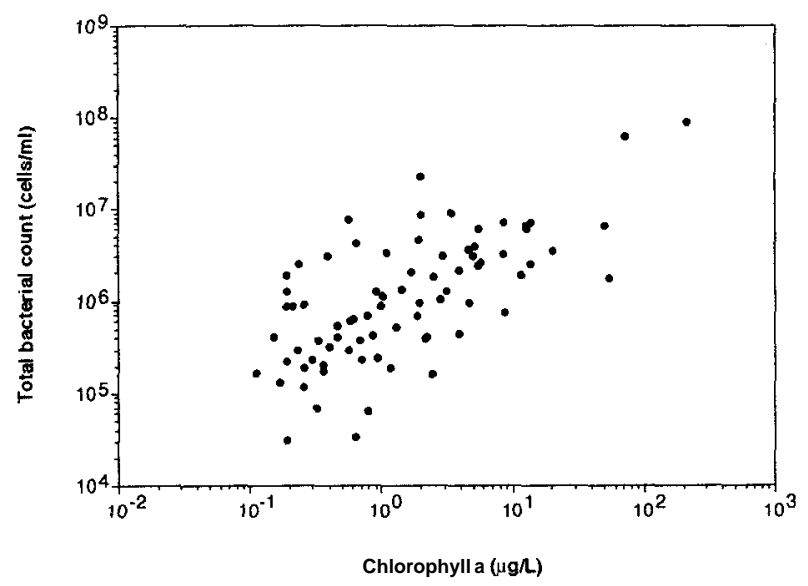

Figure 2. Relationship between bacterial total abundance and chlorophyll $a$ in the aquatic ecosystems studied by MONTES (1990). 
size (fig. 3A). If the spectrum is broken down into groups with a more or less similar function (fig. $3 \mathrm{~B}$ ), each group is seen to have a different type of relationship, as shown by the different slopes of the regressions. This secondary scaling is thought to reflect the presence of different functional groups, each with a different slope (DICKIE et al., 1987; RODRIGUEZ et al., 1990).

d) Although the abundance of ciliates, rotifers and copepods has received considerable attention in a wide variety of habitats, actual feeding studies have been carried out only in a few systems. This aspect has been analyzed in the Butron river and Lake Ciso.

In the Butron river GONZALEZ et al. (1990) analyzed the effects of protozoan ingestion and digestion rates on the survival of two enteric bacteria: Escherichia coli and Enterobacter faecalis. Fluorescently labeled bacteria (FLB) were prepared from these two microorganisms and fed to flagellated and ciliated protozoa. In one experiment the disappearance of the FLB was followed in long term (5 days) experiments (fig. 4A). Both bacterial strains dissappeared much faster in the presence than in the absence of natural microbiota (including the bacterivorous protists), although E. coli disappeared much faster. In short term experiments $(30 \mathrm{~min})$ ingestion rates were similar for both
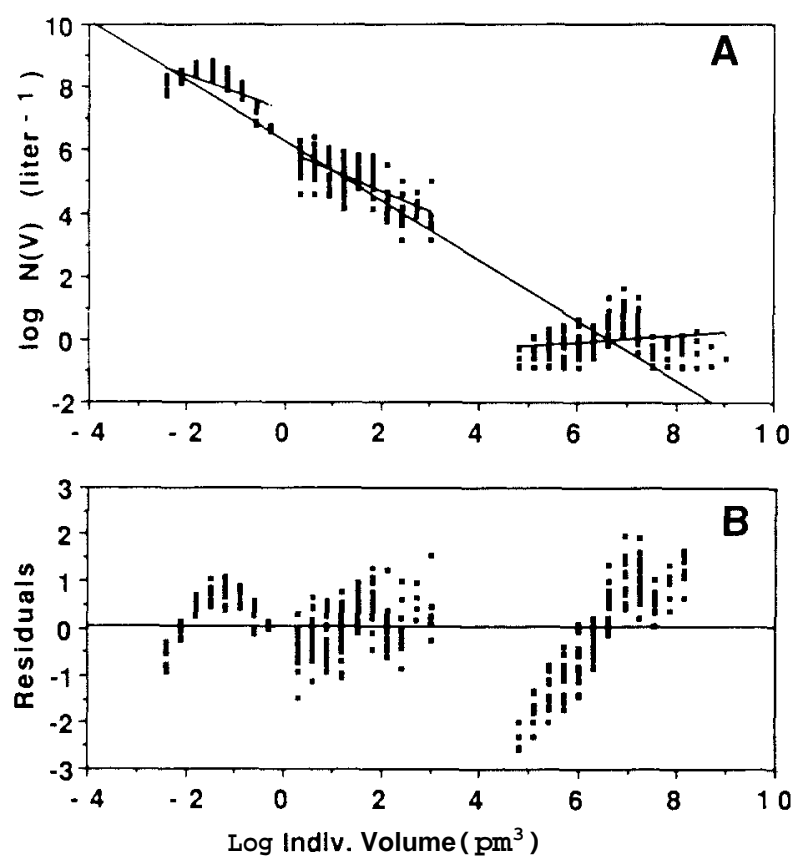

Figure 3. A. Size spectrum for Lake La Caldera. B. Distribution of the residual variance from the regression in part A. Three different groups appear which in A could be shown to have different slopes (Reproduced with permission from RODRIGUEZ et al., 1990). bacteria, but digestion rates were considerably slower for E. faecalis (fig. 4B). This suggested that the longer persistence of E. faecalis as opposed to E. coli could be explained by a differential digestion rate by the bacterivorous protists (GONZALEZ et al., 1990).

In a separate study, BARCINA et al. (199l) prepared FLB from river bacterioplankton and determined feeding rates by the flagellated and ciliated protozoa of the river Butrón. Clearance rates were between 0.2 and $8.9 \mathrm{nl} \mathrm{cell}^{-1} \mathrm{~h}^{-1}$ for flagellates and 3.9 to $367.3 \mathrm{nl} \mathrm{cell}^{-1} \mathrm{~h}^{-1}$ for ciliates. The global impact of flagellates, however, was about 6 times higher than that of ciliates, since flagellates were more abundant (600 to 4000 ind. $\mathrm{mL}^{-1}$ ) than ciliates ( 1 to 7 ind. $\mathrm{mL}^{-1}$ ).

In Lake Ciso, protistan populations are sharply stratified (fig. 5). Flagellates are of secondary importance in this system. They are only present in the epilimnion, where only heterotrophic bacteria are available as food. In the metalimnion, on the other hand, enormous populations of Cryptomonas phaseolus, purple sulfur bacteria, and heterotrophic bacteria are available as food (fig. SA). This biomass is
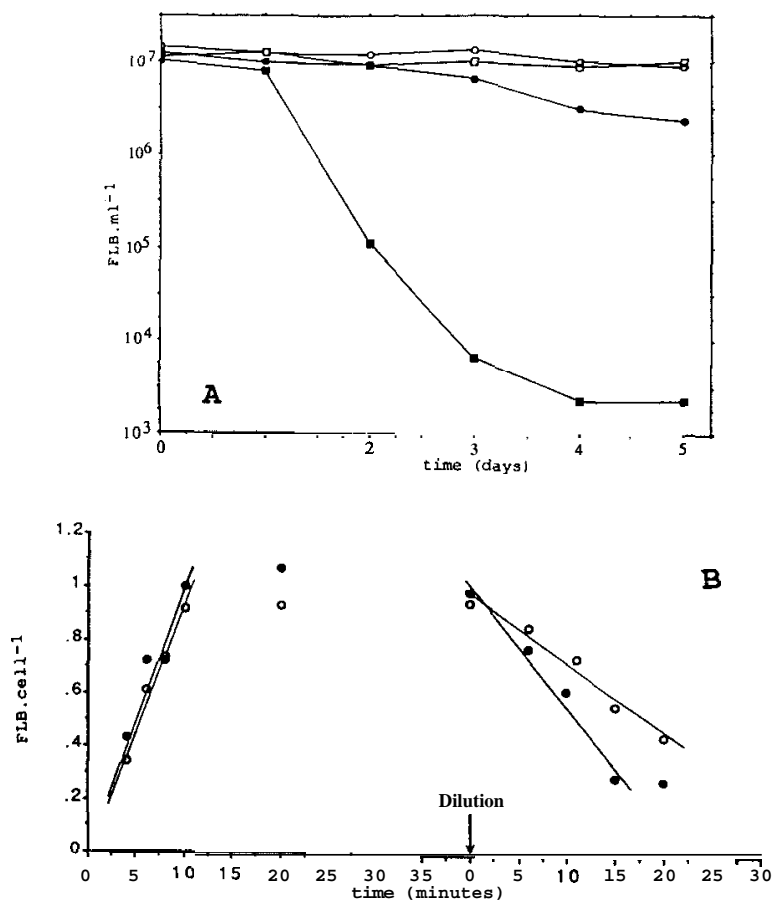

Figure 4. A. Long-term experiment following the dissapearance with time of Escherichia coli FLB in the presence $(\mathbf{U})$ and absence $(U)$ of natural microbiota and Enterococcus faecalis FLB in the presence (O) and absence (O) of natural microbiota. B. Ingestion and digestion rates of the natural microbiota feeding on Escherichia coli FLB ( 0 ) and Enterococcus faecalis FLB $(O)$. (Reproduced with permission from GONZALEZ et al., 1990). 
cropped by a collection of both aerobic and anaerobic ciliates, plus some rotifers.

Groups of two species of ciliates seem to exploit approximately the same resources. Coleps hirtus and Prorodon sp. both feed on Cryptomonas phaseolus besides fixing $\mathrm{CO}_{2}$ through the agency of intracellular Chlorella cells. The vertical distribution of the two, however, is slightly different: Prorodon shows tolerance to higher concentrations of sulfide (fig. 5B). In the anaerobic part of the lake, Plagiopyla ovata and Metopus es are bacterivorous, feeding on both large aggregates of purple sulfur bacteria and smaller heterotrophic bacteria. Certain aerobic ciliates appear at given times of the year, forming metalimnetic blooms, such as Vorticella and Paramecium, but they are not a permanent feature of the community. These ciliates seem to appear in the spring and disappear during the summer, when the bacterivorous rotifer Anuraeopsis fissa appears (GASOL et al., 1992; MASSANA et al., in preparation).

$F L B$ have been prepared from both purple sulfur bacteria and heterotrophic bacteria, and the feeding rates have been determined. Likewise, feeding experiments with radioactively labeled Cryptomonas have been performed. In this way, the global impact of the protistan assemblage could be calculated. It was shown that a very small percentage of the biomass was cropped every day in all cases. This would explain the enormous biomass of prey cells present in the system despite very slow growth rates (MASSANA et al., in preparation).

e) and $\mathbf{f}$ ) No studies of nutrient cycling or transfer to fishes have been performed yet in Spain. A project, howe-

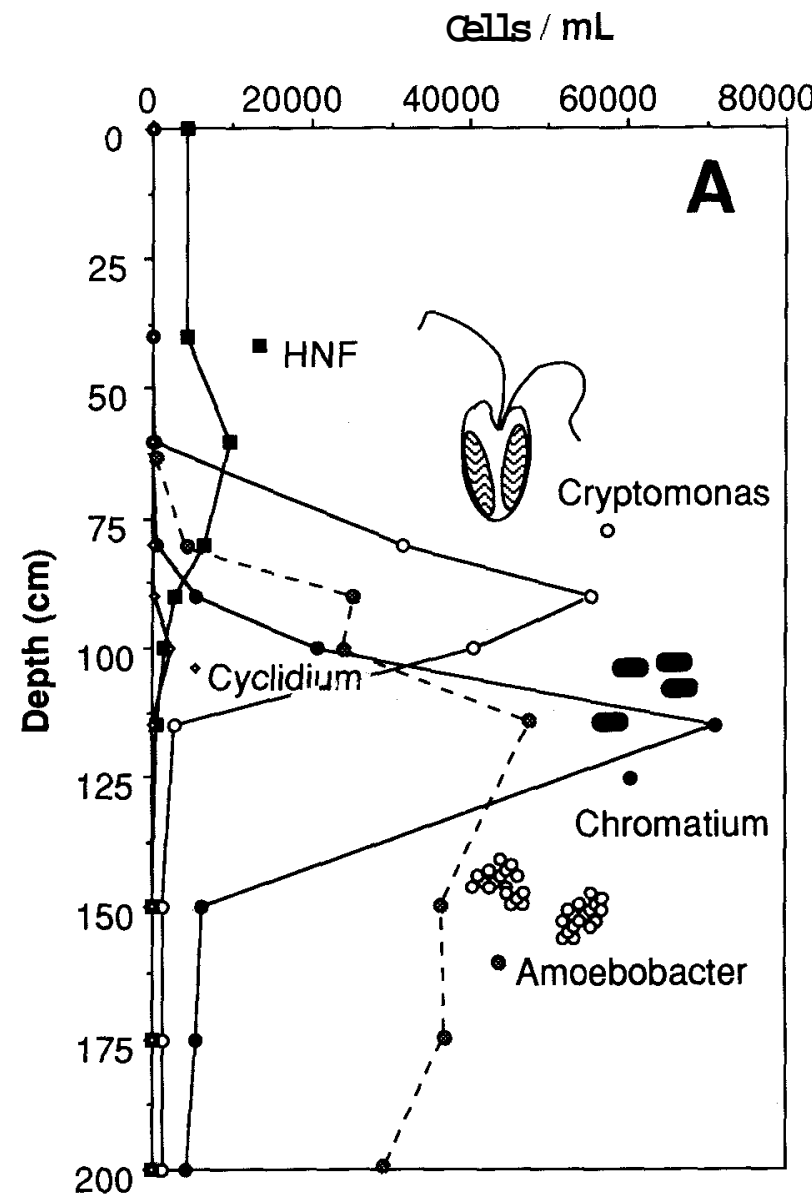

\section{Log (Cells / mL)}

$\begin{array}{llllllllll}0.5 & 0.0 & 0.5 & 1.0 & 1.5 & 2.0 & 2.5 & 3.0 & 3.5 & 4.0\end{array}$

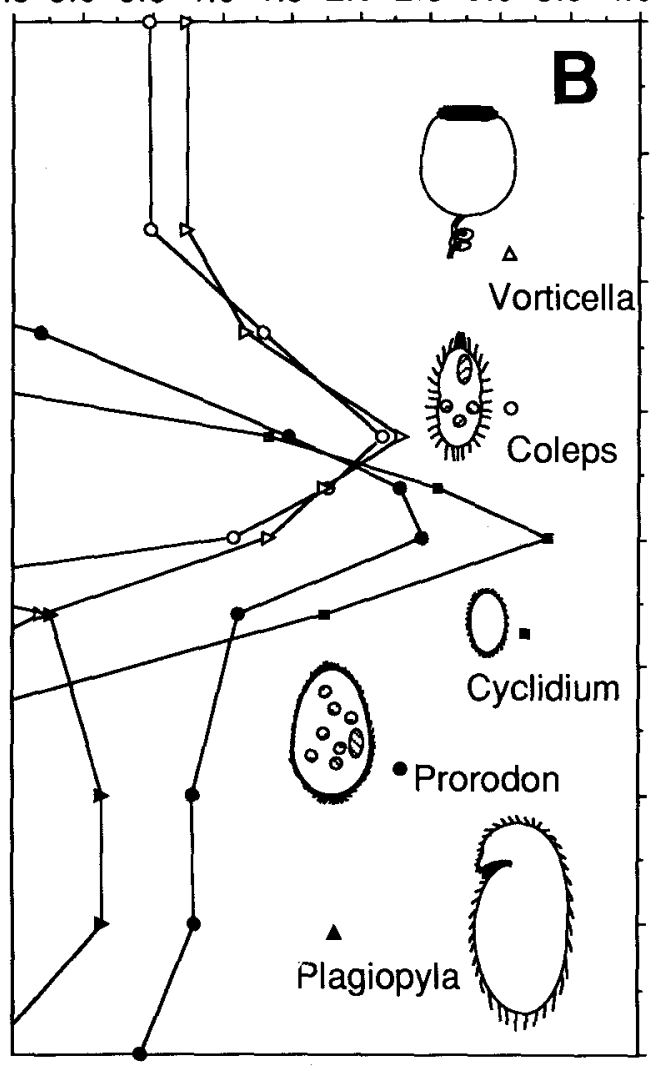

0

50

75

100

Figure 5. A. Vertical distribution of phototrophic microorganisms in Lake Cisó. The distribution of the bacterivorous ciliate Cyclidium and heterotrophic nanoflagellates (HNF) are shown for comparison of abundance scales. B. Vertical distribution of ciliates in Lake Ciso. (Unpublished data of R. Massana for June 11, 1991). 
ver, has been initiated in Lake La Caldera (Granada) to determine the effects of zooplankton on phosphorous recycling in this oligotrophic high-mountain lake (L. CRUZPIZARRO, personal communication).

\section{THE ECOLOGY OF AUTOTROPHIC PROKARYOTES}

\section{Distribution of phototrophic bacteria}

Several authors have described the presence of autotrophic bacteria in many aquatic ecosystems (fig. 1). GUERRERO et al. (1987) reviewed information about many water bodies in the Mediterranean region of Spain. Further detailed studies have been conducted in the karstic lakes of Cuenca (MIRACLE et $a l$., 1992; VICENTE \& MIRACLE, 1984, 1988). Their presence has also been noted in karstic lakes in the Pre-Pyreneean region (CAMPS et al., 1976; AVILA et $a l ., 1984$; GUERRERO et $a l ., 1987$ ) and in coastal lagoons such as La Massona (RIERA \& ABELLÀ 1986, 1991), El Remolar (GUERRERO et al., 1987), Cullera (MIRACLE \& VICENTE 1985) and Cibollar (MOYÀ et $a l$., 1987). Finally, the survey of Spanish continental systems (MONTES 1990) provided a wealth of information on the distribution of phototrophic bacteria throughout the country. Only a brief summary is possible here.

There are three types of aquatic environments where phototrophic bacteria are usually present: inland hypersaline shallow lakes and salterns, coastal lagoons with freshwater above marine water, and karstic lakes. Spanish hypersaline systems almost always show the presence of microbial mats (GUERRERO \& DE WIT, 1992), while the other two types of systems usually have layers of planktonic purple or green sulfur bacteria at the thermocline or chemocline (MIRACLE \& VICENTE, 1985; MOYÀ et al., 1987; RIERA \& ABELLÀ, 1986, 1991; GUERRERO \& DE WIT, 1992; MIRACLE et al., 1992).

Due to the generally dry climate evaporation is strong and, as aconsequence, hypersaline systems are very abundant and extremely diverse in Spain (MONTES \& MARTINO, 1987). In addition endorheic areas are quite extensive. Therefore, comercially exploited and abandoned salterns are quite frequent both in coastal areas (such as Santa Pola in Alicante) and in the interior (for example in the shallow lake of Quero, in Ciudad Real). Other shallow lakes are athalassohaline, with magnesium as the dominant anion, such as Chiprana (Zaragoza, GUERRERO et al.,
1991) or Pétrola (Albacete). Tide pools and marsh areas also become frequently hypersaline such as in the Alfacs Bay in the Ebro Delta (ESTEVE et al., 1992b). Most of these have been shown to have microbial mats with different degrees of development. The variety of chemistries and hydrological conditions suggest a diversity of species and adaptation mechanisms which should be extremely interesting to study.

Most of the planktonic communities of phototrophic bacteria are found in karstic lakes and coastal lagoons. Karstic lakes are very frequent in the Eastern portion of the Iberian Peninsula, which is mostly calcareous (fig. 1). A classification of such systems is given in GUERRERO et al. (1987). A more detailed scheme of karstic lakes can be found in MIRACLE et al. (1992). These are usually deep, round shaped, dolines formed by dissolution and collapse of the terrain. If gypsum layers occur the lakes have high sulfate concentration (for example in the Banyoles area, sulfate concentrations are about half of those in sea water). On the other hand, some of the torcas in Cuenca are very low in sulfate (for example Laguna de la Cruz, VICENTE \& MIRACLE, 1984, 1988). The presence of sulfate is important because it usually results in sulfate reduction by bacteria (Desulfovibrio-like), and consequently in the production of sulfide in the lower layers of lakes. This sulfide provides reducing power for the phototrophic sulfur bacteria and allows their development if enough light reaches the anaerobic waters (MIRACLE et al., 1992).

The coastal lagoons are usually old river mouths, with marine water under a layer of freshwater. In these cases, sulfate concentrations are the usual ones in sea water and sulfide is always present. The particular species of phototrophic bacteria seem to be different from those found in freshwaters (MIRACLE \& VICENTE, 1985; MOYÀ et al., 1987; RIERA \& ABELLÀ, 1986, 1991).

GUERRERO et al. (1987) attempted a biogeography of sulfur phototrophic bacteria. They noted a significant trend for species of purple bacteria with the carotenoid okenone to be dominant in planktonic systems, unlike in laboratory isolates. However, since most identifications of strains rely on isolation of pure cultures, a true species distribution has not been possible.

Planktonic phototrophic bacteria are always found in layers below the sulfide-oxygen interface. Usually, low light intensities in this region are sufficient to allow slow growth of the bacteria, while sulfide from below provides the necessary reducing power. 
Light determines whether green or purple sulfur bacteria dominate planktonic communities. This was shown by MONTESINOS et al. (1983) and MONTESINOS \& ESTEVE (1984). These authors showed how purple bacteria were, in general, more abundant when epilimnetic algae were few or absent. Green bacteria were dominant in the opposite case. Green bacteria also tended to be more abundant in lakes where the sulfideoxygen interface was deep than in lakes where it was shallow. In fact, the presence of purple bacteria was shown to affect the quality of light in Lake Ciso in such a way that Chlorobium limicola was present, while Chlorobium phaeobacteroides dominated in the absence of purple bacteria (MONTESINOS et al., 1983).

It is interesting to note that accumulations of phototrophic bacteria are usually accompanied by similar layers of other organisms. In particular Oscillatoria spp. and Cryptomonas spp. have been found slightly above or below the layers of phototrophic bacteria in several lakes (MIRACLE et al., 1992). These layers of primary producers coexist with heterotrophic organisms. In particular, ciliates such as Coleps hirtus and rotifers (see below) form extremely dense layers above those of phototrophs. Thus, starting from above, one usually encounters a rotifer, Chlorella bearing ciliates such as Coleps or Prorodon, Cryptomonas or a cyanobacterium, purple bacteria, and green bacteria. These layered structure is analogous to that found in the benthic microbial mats, but spans $\mathrm{cm}$ or $\mathrm{m}$ instead of $\mathrm{mm}$. The whole community has been shown to migrate vertically through diel cycles in Lake Cisó (GASOL er al., 1991a; PEDROS-ALIO \& SALA, 1990).

\section{Growth}

Production of autotrophic bacteria has been determined in Cullera, where green sulfur bacteria predominate (MIRACLE \& VICENTE, 1985) and in Lake Cisó, where purple bacteria are generally more important (GARCIA CANTIZANO et al., 1987). In both cases the bacteria were observed growing very slowly. In Lake Cisó, doubling times ranged from 5 to 50 days (MAS et al., 1990; PEDROS-ALIO er al., in prep.). This extremely slow growth was caused by light limitation, as shown by the enhanced $\mathrm{CO}_{2}$ fixation when bacterial samples were incubated at light intensities higher than ambient (MIRACLE \& VICENTE, 1985; GUERRERO et al., 1985). Neither sulfide nor phosphate enhanced $\mathrm{CO}_{2}$ fixation in Lake Cisó.

\section{Losses}

The enormous biomasses accumulated by sulfur phototrophic bacteria with such slow growth rates would argue for little losses. Sedimentation, decomposition, and washout were measured in Lake Cisó through a year cycle (MAS et al., 1990). Estimates of these losses were in agreement with slow growth, but the impact of predation had not been determined and, thus, it remained as a possibility. Potential predators such as the anaerobic ciliates Caenomorpha, Plagiopyla and Metopus, or metalimnetic Scuticociliates, Coleps or Prorodon have been found and identified in Arcas-2 (FINLAY er al., 1991). These ciliates were also found in Lake Cisó (DYER et al., 1986) but their quantitative importance had not been determined until recently (fig 5; MASSANA et al., in prep.).

Another potential cause of predatory losses was the accumulation of rotifers in the metalimnion, which has been recorded in most meromictic lakes studied (GUERRERO et al., 1978; MIRACLE \& VICENTE, 1983; GASOL et al., 1992). One of the most frequently found rotifers is Anuraeopsis fissa and its congenere A. miraclei. The former has been found in Lake Cisó (PEDROS-ALIO et al., 1986), Laguna de la Cruz and Lagunillo del Tejo (MIRACLE \& VICENTE, 1983), forming abundant masses at the upper part of the metalimnion (up to $10^{3}$ individuals $\mathrm{mL}^{-1}$ in Lake Cisó). Several other rotifers have been found to accumulate at the metalimnion of meromictic lakes: Synchaeta grimpei, S. tremula, Notholca salina and others in Cullera, Filinia terminalis , F, hofmanni and A. fissa in basin III of Lake Banyoles, and F. hofmanni and Keratella quadrata in Laguna de la Cruz (GUERRERO et al., 1978; MIRACLE \& VICENTE, 1983; MIRACLE et al., 1992).

Since dense layers of phototrophic bacteria are found slightly below rotifer and ciliate accumulations in all cases, it is tempting to assume a trophic relationship. Moreover purple sulfur bacteria have been observed in the interior of several of these ciliates (FINLAY et al., 1991), and several of the rotifers were known to be at least partially bacterivorous. MASSANA and PEDROS-ALIO (in prep.) carried out experiments with fluorescently labeled heterotrophic and purple sulfur bacteria in Lake Cisó to quantify this potential relationship. It could be shown that both ciliates and rotifers were able to feed on the bacteria in experimental bottles. In the lake, however, the populations of predators and prey were slightly separated in space and, thus, the impact of predation was very small for the phototrophic bacteria. 


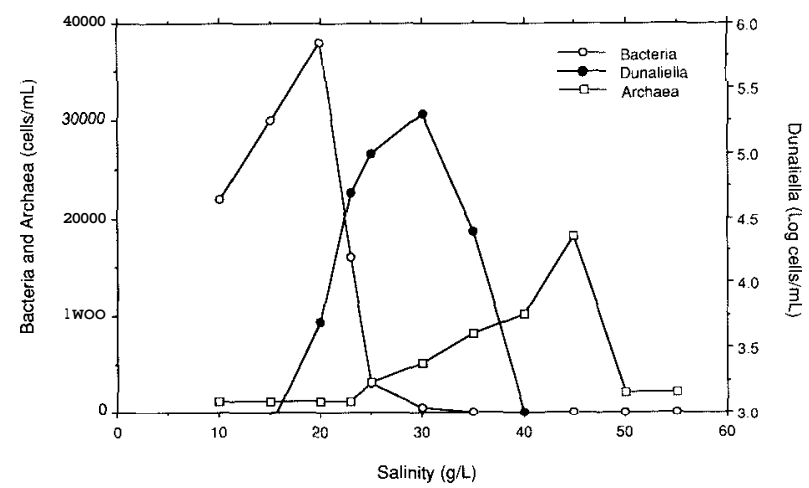

Figure 6. Abundance of the phototrophic eukaryote Dunaliella sp. (C) along a salinity gradient in the Santa Pola salterns, and average counts of nonpigmented colonies (bacteria, $\mathbf{O}$ ) and pigmented colonies (archaea, U) in different media inoculated with samples from ponds of different salinities. (Redrawn, with permission, from RODRIGUEZ-VALERA et al., 198I, 1985).

The last possible source of predatory losses is the existence of predatory bacteria and viruses. Viruses have not been studied in this context, but the existence of several predatory bacteria has been shown in Lakes Estanya (ESTEVE et al., 1983, 1992a; GUERRERO et al., 1986), Arcas-2 (VICENTE et al., 1991), Ciso (GUERRERO et al., 1986; ESTEVE et al., 1992a; GAJU et al., 1992) and Vilar (GAJU et al., 1992) always attacking purple sulfur bacteria. These predatory bacteria tend to be more abundant where the purple bacteria are less active, that is, in the deeper parts of the bacterial layer, suggesting that their role is that of opportunistic scavengers. Their real impact, however, remains to be assessed.

In summary, biomass and production of phototrophic bacteria are controled by the light intensity reaching their depths. Species composition, on the other hand, is controlled by the light quality and the amount of sulfide present. These organisms generally form enormous accumulations of biomass despite slow growth thanks to small losses. In particular predators are not efficient at cropping this biomass. Alltogether, the studies of phototrophic bacteria in Spanish ecosystems constitute the most complete study of the ecology of any particular group of bacteria available.

\section{STUDIES OF HYPERSALINE ENVIRONMENTS}

Another type of system which has received some attention is that of hypersaline environments. Although not centered on the microbial ecology of the salterns, the studies provided interesting ecological information on the distribution of halophilic microorganisms (RODRIGUEZ-VALERA, 1986). The system studied was the Santa Pola salterns (fig. 1) in Alicante. These salterns provided a series of ponds of increasing salinity, from seawater up to salt saturation. Samples from the ponds were spread on agar plates with different media for halophilic bacteria (RODRIGUEZ-VALERA et al., 1981). Essentially all halotolerant bacteria disappeared at salinities above $10 \%$ total salts (w/v). Only halophilic bacteria remained (fig. 6). These could be divided into moderate halophiles, found from 10 to $25 \%$ o salinity, and extreme halophiles, found from $25 \%$ salinity to saturation. The former were a diverse assemblage of eubacteria, including Pseudomonas, Alcaligenes and other bacteria (RODRIGUEZ-VALERA et al., 1985). The latter, on the other hand, were exclusively archaea of the genera Halobacterium, Halococcus and Haloarcula (RODRIGUEZ-VALERA et al., 1985). Most of the eukaryotic microorganisms disappeared above 15\% salinities, except Dunaliella which had its maximal abundance at $25 \%$ salinity, with $10^{5}$ cells $\mathrm{m} \sim$-(fig. 6 ). Finally, microbial mats were found in most ponds, with higher diversity of microorganisms at about $10 \%$ salts. These ponds should provide an excellent laboratory for studies of microbial ecology.

\section{CONCLUSION}

Due to its climate and topography, Spain provides a rich variety of permanent and temporary wetlands. Many of these systems are hypersaline, anaerobic or both. Thus, they are extremely interesting from the microbial point of view. The recently carried out survey of Spanish wetlands (MONTES, 1990) has been instrumental in providing an upto-date catalog of available systems. It should be possible to use such a wide array of aquatic systems as a natural laboratory for experimental microbial ecology.

\section{REFERENCES}

AVILA, A., J.L. BURRELL, A. DOMINGO, E. FER NANDEZ, J. GODALL, \& J.M. LLOPART, 1984. Limnología del Lago Grande de Estanya. Oecol. Aquat. 7: 3-24.

AZAM, F., T. FENCHEL, J.G. FIELD, J.S. GREY, L.A. MEYER-REIL, \& F. THINGSTAD, 1983. The ecological role of water-column microbes in the sea. Mar. Ecol. Progr. Ser. 10: 257-263. 
BARCINA, I., B. AYO, A. MUELA, L. EGEA, \& J. IRIBERRI, 1991. Predation rates of flagellate and ciliated protozoa on bacterioplankton in a river. FEMS Microbiol. Ecol. 85: 141-150.

BIRD, D.F., \& J. KALFF, 1984. Empirical relationship between bacterial abundance and chlorophyll concentration in fresh and marine waters. Can.J.Fish. Aquat.Sci. 41: 1015-1023.

BROCK, T.D., 1966. Principles of Microbial Ecology.

Prentice Hall, Englewood Cliffs, New York

CAMPS. J., I. GONZALVO, J. GÜELL, P. LOPEZ, A. TEJERO, X. TOLDRA, F. VALLESPINOS, $\&$ M. VICENS. 1976. El lago de Montcortés, descripcionde un ciclo anual. Oecol. aquat 2: 99-110.

COLE, J.J., S. FSNDLAY, \& M.L. PACE, 1988. Bacterial production in fresh and saltwater ecosystems: a cross-system overview. Mar. Ecol. Prog. Ser. 43: 1-10.

DICKIE, L.M., S.R. KERR, \& P.R. BOUDREAU, 1987. Size dependent processes underlying regularities in ecosystem structure. Ecol. Monogr. 57: 233-250.

DUCKLOW, H.W., \& C.A. CARLSON, 1992. Oceanic bacterial production. Adv. Microbial Ecol. 12 (in press).

DYER, B.B., N. GAJU, C. PEDROS-ALIO, I. ESTEVE, \& R. GUERRERO, 1986. Ciliates from a freshwater sulfuretum. Biosystems 19: 127-135.

ECHEVARRIA, F., 1991. Variabilidad espacio-temporal de la estructura de tamaños del plancton en dos ecosistemas acuáticos epicontinentales. Ph. D. Thesis, University of Málaga.

ECHEVARRIA, F., P. CARRILLO, F. JIMENEZ, P. SANCHEZ-CASTILLO, L. CRUZ-PIZARRO, \& J. RODRIGUEZ, 1990. The size-abundance distribution and taxonomic composition of plankton in an oligotrophic, high mountain lake (La Caldera, Sierra Nevada, Spain). J. Plankton Res. 12: 415-422.

ESTEVE, I., R. GUERRERO, E. MONTESINOS, \& C. ABELLÀ, 1983. Electron microscopy study of the interaction of epibiontic bacteria with Chromatium minus in natural habitats.. Microb. Ecol. 9: 57-64.

ESTEVE, I., N. GAJU, J. MIR \& R. GUERRERO, 1992a. Comparison of techniques to determine the abundance of predatory bacteria attacking Chromatiaceae. FEMS Microhiol. Ecol., 86: 205-211.

ESTEVE, I., M. MARTINEZ ALONSO, J. MIR \& R. GUERRERO, 1992b. Distribution, typology and structure of microbial mat communities in Spain. Preliminary studies. Limnetica 8.

FINLAY, B.J., K.J. CLARKE, E. VICENTE, \& M.R. MIRACLE, 1991. Anaerobic ciliates from a sulphide-rich solution lake in Spain. Europ. J. Protistol. 27: 148-159.
GAJU, N., I. ESTEVE \& R. GUERRERO, 1992. Distribution of predatory bacteria that attack Chromatiaceae in a sulfureous lake. Microbiol. Ecol., (in press).

GARCíA CANTIZANO, J., J.M. GASOL, \& C. PEDRÓS-ALIÓ, 1987. Producción primaria por fototrofía y por quimiotrofia en la laguna de Cisó. Actas IV Cong.Esp. Limnología (Sevilla) pp. 75-84.

GASOL, J.M., J. GARCíA-CANTIZANO, R. MASSANA, F. PETERS, R. GUERRERO, \& C. PEDROS-ALIO, 1991 a. Diel changes in the microstratification of the metalimnetic community in Lake Ciso. Hydrobiologia 211: 227-240.

GASOL, J.M., R. GUERRERO \& C. PEDROS-ALIO, $1991 \mathrm{~b}$. Seasonal variations in size structure and procaryotic dominance in sulfurous Lake Ciso. Limnol. Oceanogr. 36: 860-872.

GASOL, J.M., F. PETERS, R. GUERRERO, \& C. PEDRÓS-ALIÓ, 1992. Community structure in Lake Ciso: Biomass allocation to trophic groups and differing patterns of seasonal succession in the meta- and epilimnion. Arch. Hydrobiol. 123: 275-303.

GILABERT, J., J. RODRIGUEZ, \& F. JIMENEZGOMEZ, 1990. The planktonic size-abundance spectrum in an oligotrophic, hypersaline coastal lagoon, the Mar Menor, Murcia, Spain. Proc. 24th Europ. Mar. Biol. Symp., M. Barnes and $R N$ Gibson (eds.), Trophic relationships in the marine environment, Aberdeen U.P. : 18-27.

GONZALEZ, J.M., J. IRIBERRI, L. EGEA, \& I. BARCINA, 1990. Differential rates of digestion of bacteria by freshwater and marine phagotrophic protozoa. Appl. Environ. Microbiol. 56: 1851-1857.

GUERRERO, M.C. \& R. DE WIT, 1992. Microbial mats in the inland saline lakes of Spain. Limnetica 8.

GUERRERO, M.C., J, BALSA, M. PASCUAL, B. MARTSNEZ \& C. MONTES, 1991. Caracterizacion limnológica de la laguna salada de Chiprana y sus comunidades de bacterias fototroficas. Limnetica 7: 83-96

GUERRERO, R., C.A. ABELLA, \& M.R. MIRACLE, 1978. Spatial and temporal distribution of bacteria in a meromictic karstic lake basin: relationship with physicochemical parameters and zooplankton.. Verh. Internat. Verein. Limnol. 20: 2264-2274.

GUERRERO, R., E. MONTESINOS, C. PEDROS-ALIO, I. ESTEVE, J. MAS, H. VAN GEMERDEN. P.A.G. HOFMAN, \& J.F. BAKKER, 1985. Phototrophic sulfur bacteria in two Spanish lakes: Vertical distribution and limiting factors. Limnol. Oceanogr. 30: 919-931.

GUERRERO, R., C. PEDROS-ALIO, I. ESTEVE, J. MAS, D. CHASE, \& L. MARGULIS, 1986. Predatory 
prokaryotes: predation and primary consumption evolved in bacteria. Proc. Natl. Acad. Sci. USA 83: 2138-2142.

GUERRERO, R., C. PEDROS-ALIO, I. ESTEVE, \& J. MAS, 1987. Communities of phototrophic sulfur bacteria in lakes of the Spanish mediterranean region. Acta Academ. Ahoen. 47: 125-151.

IRIBERRI, J., M. UNANUE, B. AYO, I. BARCINA, \& L. EGEA, 1990a. Bacterial production and growth rate estimation from $[3 \mathrm{H}]$ thymidine incorporation for attached and free-living bacteria in aquatic systems. Appl. Environ. Microhiol. 56: 483-487.

IRIBERRI, J., M. UNANUE, B. AYO, I. BARCINA, \& L. EGEA, 1990b. Attached and free-living dividing bacteria in two aquatic systems. Letters Appl. Microhiol. 11: 87-89.

MAS, J., C. PEDROS-ALIO, \& R. GUERRERO, 1990. In situ specific loss and growth rates of purple sulfur bacteria in Lake Cisó. FEMS Microbiol. Ecol. 73: 271-281.

MIRACLE, M.R., \& E. VICENTE, 1983. Vertical distribution and rotifer concentrations in the chemocline of meromictic lakes. Hydrobiologia 104: 259-267.

MIRACLE, M.R., \& E. VICENTE, 1985. Phytoplankton and photosynthetic bacterial sulfur bacteria productionin the meromictic coastal lagoon of Cullera (Valencia, Spain). Verh. Internat. Verein. Limnol. 22: 2214-2220.

MIRACLE, M.R., E. VICENTE \& C. PEDROS-ALIO, 1992. Biological studies in Spanish meromictic and stratified karstic lakes. Limnetica 8.

MONTES, C \& P. MARTINO, 1987. Las lagunas salinas españolas. In: Seminario sobre bases científicas para la protección de las humedades en España: 95-145. Real Academia de Ciencias de Madrid.

MONTES, C. (Coord.), 1990. Estudio de las zonas húmedas de la España peninsular. Inventario y tipificación. INITEC, Ministerio de Obras Públicas y Urbanismo. Madrid.

MONTESINOS, E., \& I. ESTEVE, 1984. Effect of algal shading on the net growth and production of phototrophic sulfur bacteria in lakes of the Banyoles karstic area.. Verh. Internat. Verein. Limnol. 22: 1102-1105.

MONTESINOS, E., R. GUERRERO, C. ABELLA, \& I. ESTEVE, 1983. Ecology and physiology of the competition for light between Chlorobium limicola and Chlorobium phaeobacteroides in natural habitats. Appl. Environ. Microbiol. 46: 1007-1016.

MOYA, G., G. RAMON, A. MARTíNEZ TABERNER, V. FORTEZA, C. PICO, C. PONSELL, R. ROSSELLO, \& M.A. SOBERATS, 1987. Limnology of a meromictic coastal lagoon, L'Estany Cibollar (Majorca, Balearic Islands). Limnetica 3(2): 255-262.
PEDROS-ALIO, C., J.M. GASOL, \& R. GUERRERO, 1986. Microbial ecology of sulfurous Lake Cisó. In.: F. Megusar \& M. Gantar (Eds). Perspectives in Microbial Ecology. Slovenian Soc. Microhiol, Ljubjana, Yugoslavia : 638-643.

PEDROS-ALIO, C., \& M.M. SALA, 1990. Microdistribution and diel vertical migration of flagellated vs. gasvacuolate purple sulfur bacteria in a stratified water body. Limnol. Oceanogr. 35: 1637-1644.

POMEROY, L.R.. 1974. The ocean's food web, a changing paradigm. BioScience 24: 499-504.

RIERA, X G. \& C.A. ABELLA, 1986. Dinàmica anual de les poblacions de bacteris fototrbfics de la llacuna costanera de La Massona (Alt Emporda, Girona). Scientia gerund. 12: 35-48.

RIERA, X G. \& C.A. ABELLA, 1991. Limnological cycle of the coastal lagoon La Massona (Girona, NE Spain). Origin, dynamics and influence of the sporadic sewater infalls on the meromixis. Verh. Internat. Verein. Limnol. 24: 1029-1031.

RODRIGUEZ, J., F. ECHEVARRIA, \& F. JIMENEZGOMEZ, 1990. Physiological and ecological scalings of body size in an oligotrophic, high mountain lake (La Caldera, Sierra Nevada, Spain). J. Plank. Res. 12: 593-599.

RODRIGUEZ-VALERA, F., 1986. The ecology and taxonomy of aerobic chemoorganotrophic halophilic eubacteria. FEMS Microhiol. Reviews 39: 17-22.

RODRIGUEZ-VALERA, F., F. RUIZ-BERRAQUERO, \& A. RAMOS-CORMENZANA, 1981. Characteristics of the heterotrophic bacterial populations in hypersaline environments of different salt concentrations. Microb. Ecol. 7: 235-243.

RODRIGUEZ-VALERA, F., A. VENTOSA, G. JUEZ, \& J.F. IMHOFF, 1985. Variation of environmental features and microbial populations with salt concentrations in a multi-pond saltern. Microh. Ecol. 11: 107-115.

VICENTE, E., \& M.R. MIRACLE, 1984. Distribution of photosynthetic organisms in a temporal stratified karstic pond near Cuenca (Spain). Verh. Internat. Verein. Limnol. 22: $1504-1710$

VICENTE, E., \& M.R. MIRACLE, 1988. Physicochemical and microbial stratification in a meromictic karstic lake of Spain. Verh. Internat. Verein. Limnol. 23: 522-529.

VICENTE, E., M.A. RODRIGO, A. CAMACHO, \& M.R. MIRACLE, 1991. Phototrophic prokaryotes in a karstic sulphate lake. Verh. Internat. Verein. Limnol. 24: 998-1004.

WILLIAMS, W.D., 1988. Limnological imbalances: an antipodan viewpoint. Freshwat. Biol. 20: 407-420. 